\title{
The Environment, Energy and Economic Impacts of Carbon Tax and Indirect Tax in the Coal Industry
}

\author{
Jingmin Wang ${ }^{1,2}$, Chen Zhao ${ }^{1 *}$ \\ ${ }^{1}$ School of Economics and Management, North China Electric Power University, Baoding, China \\ ${ }^{2}$ Beijing Key Laboratory of New Energy and Low-Carbon Development \\ (North China Electric Power University), Changping Beijing, China
}

Received: 16 June 2018

Accepted: 24 September 2018

\begin{abstract}
The $\mathrm{CO}_{2}$ emissions from China's coal consumption account for $14.3 \%$ of the world's $\mathrm{CO}_{2}$ emissions. The taxation of China's coal industry affects the progress of world emissions reduction to some extent. This paper establishes six countermeasure scenarios with different tax systems considering carbon tax and indirect tax, then constructs a dynamic recursive computable general equilibrium model to simulate the tax system changes of the coal industry. It turns out that in both rural and urban populations, coal consumption is more sensitive to the carbon tax and indirect tax compared with the consumption of other commodities. The reduction effect of increasing tax will grow and social reduction cost will be reduced over time. Increasing the coal industry tax can reduce $\mathrm{CO}_{2}$ emissions significantly and will suffer relatively less GDP loss, for example increasing $20 \%$ of indirect tax on the coal industry will lead to 3.65 billion tons of $\mathrm{CO}_{2}$ reduction during 2018-2030, accounting for $10.05 \%$ of 2015 world $\mathrm{CO}_{2}$ emissions. We found that increasing taxes can improve all industries' energy efficiency, which reflects on the powerful role of the coal industry in guiding the market to reducing $\mathrm{CO}_{2}$ emissions. Finally, these results strongly recommend that China should increase indirect tax as quickly as possible to reach the long-term interests as soon as possible.
\end{abstract}

Keywords: computable general equilibrium (CGE) model, $\mathrm{CO}_{2}$ taxation, coal industry, China, carbon tax

\section{Introduction}

The climate change caused by greenhouse gas (GHG) has become a major problem that the world needs to solve urgently. Many experts have made great

*e-mail: zcncepu2017@163.com efforts to solve the problem like $\mathrm{CO}_{2}$ reduction or energy consumption reduction $[1,2]$. They have been working on methods for sustainable development [3, 4], which involves many aspects such as nature, the environment, society, economics, technology, and politics. Different studies of researchers have different research directions. Some literature has focused on the relationship between science and the economy, such as $\mathrm{Wu}$ et al. (2010) [5] 
and Liu et al. (2017) [6]. While some have concentrated on the environment, such as Lechowska (2017) [7]. The relationship between the environment and the economy has also been studied widely. Low-carbon economy is a very hot topic nowadays, and many reduction tools have been studied or implemented, such as carbon tax (CT) [8-10], carbon sinks [11-13], and an emissions trading scheme [14-17Emission taxation (including $\mathrm{CO}_{2}$ emission tax, $\mathrm{SO}_{2}$ emission tax, etc.) is one of these emission reduction policies (such as clean development mechanism, carbon trading, etc.) by government. Many scholars have done much research related to the emissions tax. For instance, a simulation study is presented by Zhang and Zhang (2018) [18] to analyze the impact of carbon taxation on China's tourism sector on carbon emissions and economic welfare by using the CGE model. Lin and Li (2011) [19] estimated the real $\mathrm{CO}_{2}$ emission reduction effects of Five Nordic countries by employing regression analysis. They found that the tax in Finland imposes a negative impact on carbon intensity growth, and the carbon tax actually has not realized its reduction effects in some countries like Norway, as the rapid growth of oil and natural gas products drove a substantial increase of carbon emissions. Mardones and Baeza (2018) [20] set different carbon tax rates in Brazil, Mexico and Chile by using the Leontief pricing model, indicating that for the same tax rate the impact on commodity prices and $\mathrm{CO}_{2}$ emissions in each country are very different. Bonnet et al. (2018) [21] analyzed whether a $\mathrm{CO}_{2}$ taxation in France can change habits of a household with respect to animal product purchases or not, as well as the emission reduction effects of it. Mardones and Flores (2018) [22] studied different industrial tax rate effects on the reduction in emissions and tax revenue of government in Chile would generate. They found that taxes with too low or too high rates are effective in increasing revenue but not in reducing emissions. Farajzadeh (2018) [23] aimed to implement a dynamic CGE model to evaluate the effects of pollutants emissions tax, such as $\mathrm{CO}_{2}, \mathrm{SO}_{2}$, etc., on their emissions and on social welfare. Li et al. (2018) [24] analyzed the effects of regional unbalanced carbon tax, the results showing that industrial structure, energy consumption and $\mathrm{CO}_{2}$ per GDP of Liaoning Province are significantly affected by the price effect. Wang et al. (2018) [25] proposed a deterministic optimization model to acknowledge the optimal power mixed with the introduction of environmental taxes and carbon taxes. Benavides et al. (2015) [26] analyzed the economy-wide implications by applying carbon tax to the electricity generation sector in Chile. Freire-Gonzalez and Ho (2018) [27] examined 101 industries and commodities in Spain, with an energy and an environmental extension comprising 31 pollutant emissions, in order to simulate the economic and environmental effects of environmental tax reform.

Whether enhanced actions on climate change: China's intended nationally determined contributions [28] or National carbon emission trading market construction plan (power generation industry) [29] (both of which are very important and far-reaching documents published in China) excluded the regulations or controls to coal industries. It is strange that the reasons why energy production industries except for electricity are ignored. However, we can find that China has a stronger determination to reduce emissions.

In October 2016, some sources from the National Development and Reform Commission (NDRC) pointed out that after 2020, a carbon tax may be levied on other emission companies that are excluded in the ETS market to form a policy system in which all companies will fulfill their emission reduction obligations [30], which indicates that a carbon tax policy may be applied to the coal industry.

Several researchers have done the research on tax in the coal industry or coal-fired power generation enterprises. Tang et al. (2017) [31] studied the general impacts of policy of coal resource tax reform on the economy and environment in China by building a multi-sectoral dynamic CGE model, while Liu et al. (2017) [32] analyzes the same topic using different models: by taking the coal industry and coal-fired plant as the players, they have assessed the effect of the coal resource tax reform through constructing two-stage dynamic game models, and they provided a tax rate estimation that can maintain the coal industry's profits. Song et al. (2017) [33] researched the production and environmental efficiency of the coal-fired power generation industry from 2006 to 2010 under two different tax policies through employing a network slacks-based measure model. The results indicate that in this observation period, the impact of compulsory measures was better than the effect of self-motivation measures for environmental protection in China. Chen et al. (2015) [34] evaluated the environmental costs of coal firing in China in 2007 by employing a multi-regional input-output model at the provincial level, in terms of its damages from climate change externality. Jeong et al. (2008) [35] made an economic comparison between coal-fired and other power plants in the context of carbon tax in Korea. Chen et al. (2007) [36] used a CGE model to simulate the energy savings and emissions reduction effects of an energy tax or carbon tax at various tax rates in Guangdong Province.

Several studies have focused on the effect of tax on $\mathrm{CO}_{2}$ emissions reduction, such as Tang et al. (2017) [31] and Liu et al. (2017) [32]. However, they focus on coal resource tax reform. Few studies have focused on the impact of tax changes in the coal industry on energy, economy and the environment. Moreover, the changes in $\mathrm{CO}_{2}$ tax and indirect tax are most likely to affect the taxation of the coal industry. Thus, the present paper intends to compare emission reduction abilities between carbon tax and indirect tax in the coal industry, and additionally analyze the energy, economy and environmental impact of the two kinds of tax. The innovations of this paper are as follows: 
Table 1. The main abbreviations in this paper.

\begin{tabular}{|c|c|}
\hline Abbreviation & Full name \\
\hline ETS & Emissions Trading Scheme \\
\hline VA & Value-added \\
\hline VAE & Constant Elasticity of Substitution \\
\hline CES & Constant Elasticity of Transformation \\
\hline CET & Gross Domestic Product \\
\hline CO $_{2}$ & Social Accounting Matrix \\
\hline GDP & Computable General Equilibrium \\
\hline AEEI & Autonomous Energy Efficiency Improvement \\
\hline SAM & Business as Usual scenario \\
\hline CGE & Counter-measured scenario \\
\hline BAU & Indirect tax/Production tax \\
\hline CM & Carbon tax \\
\hline IT & Indirect tax and Carbon Tax \\
\hline CT & \\
\hline ICT & \\
\hline & \\
\hline
\end{tabular}

1. The present work extends the use of the dynamic recursive CGE model to analyze the impact of carbon tax and indirect tax. In addition, we explained the modeling process in more detail relative to other literature; it is hoped that this study will provide some references for following CGE modelers.

2. We compare the emission reduction abilities of carbon tax in the coal industry with that of indirect tax in China, and analyze the effects of the variations of the two tax policies on energy, environment and the economy. Coal consumption in China accounts for $14.3 \%$ of primary energy consumption in the world. Therefore, the aim of this paper is to contribute to the world's emissions reduction work.

In order to make this paper more concise and understandable, the main abbreviations are shown in Table 1.

\section{Methodology}

As the largest emitter country, China participates in global efforts actively to curb global warming. Energy consumption in China is dominated by coal. China accounts for $23 \%$ of global energy consumption and $27 \%$ of global energy consumption. Coal accounted for $62 \%$ of China's energy structure in 2016 [37]. The proportion of China's coal consumption in world primary energy consumption is shown in Fig. 1. Thus, the study in coal consumption in China is of great importance. In this way, we will offer an analysis (evaluation) of environment, energy and economic impacts of carbon tax and indirect tax in the coal industry by applying the Computable General Equilibrium (CGE) model.

\section{CGE Model}

1. The CGE model has been extensively studied for analysis of policy impact $[31,38,39]$. Different from the input-output model [40,41], the CGE model can analyze the impact of a target issue on the whole society more concisely and clearly. We have summarized 3 characteristics of the CGE model [42-44]The supply and demand function clearly reflects the behavior of producers pursuing profit maximization and consumers pursuing maximization of utility.

2. The quantity and relative price are both endogenous in the model, and the resource allocation method is determined by the general equilibrium model structure with Walras's Law.

3. The focus of this model is on simulating the physical aspect of the economic entity. The resources of the economy in the model have been fully utilized.

The basic modelling structure is according to Lin and Jia [45, 46], which consists of five blocks: production block, income-expenditure block, trade block, energypolicy block, and macroscopic-closure and marketclearing block.



Fig. 1. Proportion of China's coal consumption of world primary energy consumption. 


\section{Production Block}

It is assumed that one sector produces only one product in the CGE model. This block has 4 levels of nesting. Policy cost, value-added and energy, and intermediate input constitutes an output bundle following a Leontief function. VAE is a bundle that consists of value-added and energy following the constant elasticity of substitution (CES) function. The next level is the VA bundle and energy bundle, which consist of capital and labor, electricity and non-electricity energy (fossil energy) input following a CES function, respectively. The non-electricity energy bundle consists of coal and non-solid fuel (oil and gas) following a CES function. Because China's input-output table with 139 sectors does not separate the oil and gas industries, and the main energy consumption in China is coal, this paper does not subdivide oil and gas.

\section{Income-Expenditure Block}

This block introduces four social subjects: government, enterprise, households, and the rest of the world, which possess their own balanced approach. Government gets income through taxes (direct and indirect tax) and tariffs; and all of these revenues are used for transfer payments, consumption and savings. Enterprises gain sales revenue from commodity consumption to support expenditures of their own: indirect tax, household income, and savings. Residents (or so-called households) earn income through remuneration from enterprises and transfer payments by government, and income of residents is equal to the sum of their consumption, direct tax and savings. The trade deficit is exogenous, which is according to $[47,48]$.

\section{Trade Block}

Like most of the research, Armington's assumption is introduced into the CGE model [49-51]. By using the CES function, we can differ domestic productiondomestic consumption and import from domestic consumption. Using CET (constant elasticity of transformation) functions, we can simulate an enterprises' distributions of production in the domestic and international markets.

\section{Energy-Policy Block}

At present, at least 20 countries have imposed carbon taxes. These countries are broadly divided into two categories: the first category, such as Denmark and Netherlands, which already has a comprehensive carbon tax system, started the implementation of the carbon tax system earlier than others, with better policy efforts. The second category consists of countries that levied carbon tax in the context of a joint global emissions reduction, but implementation is not adequate. Except for the rate of carbon tax and industry coverage, other mechanisms of carbon tax are modeled following the systems of the first category countries - Denmark and the Netherlands, where the carbon tax rate is fixed and will be paid in the form of energy tax. This block can be expressed by the following equation:

$$
P L C_{i}=p_{i}^{C O 2} E M_{i}
$$

...where subscript $i$ is the industries, $E M_{i}$ is the emission by sector $i, P C L_{i}$ is the carbon tax policy cost, and $p_{i}{ }^{C O_{2}}$ denotes carbon tax rate, which is an exogenous variable. In this paper, we only research the changes of carbon tax on coal industries so that the carbon tax rate is zero in other industries.

\section{Macroscopic-Closure and Market-Clearing Block}

Three principles of market closure are considered in this model: government budget balance, foreign trade balance, and investment-saving balance. The first two balances were introduced in the Incomeexpenditure block section. As for the last balance, the CGE model assumes that all savings are transformed into investment, which means that total investment is equal to total savings. Two principles are incorporated in market clearing. One is the market clearing of Armington composite commodity. The other is factor market clearing. The former shows that all Armington commodities are used for consumption of household and government, intermediate input and savings, without surplus. The latter is that there is no unemployment in the market.

\section{Model Dynamics}

Capital depreciation is determined by the capital stock of the current period and investment. Capital

Table 2. Capital depreciation rate of each sector.

\begin{tabular}{|c|c|c|c|c|c|c|c|}
\hline Sectors & AGR & COL & O_G & PAP & CMT & FER & CMC \\
\hline The rate of depreciation & 0.05 & 0.062 & 0.065 & 0.055 & 0.055 & 0.056 & 0.055 \\
\hline Sectors & STL & EQU & ELC & CST & TRA & OTH & SER \\
\hline The rate of depreciation & 0.055 & 0.062 & 0.048 & 0.055 & 0.052 & 0.055 & 0.045 \\
\hline
\end{tabular}


Table 3. Population growth rate in this paper.

\begin{tabular}{|c|c|}
\hline Year & Population growth rate \\
\hline $2012-2015$ & $0.60 \%$ \\
\hline $2016-2020$ & $0.60 \%$ \\
\hline $2021-2025$ & $0.21 \%$ \\
\hline $2026-2030$ & $0.15 \%$ \\
\hline
\end{tabular}

stock is endogenous except for the first period, while investment is endogenous. The capital depreciation rate is illustrated in Table 2.

Labor endowment is exogenous and determined by the National Population Development Plan (2016-2030) [52]. Table 3 shows the population growth rate in this paper.

Autonomous energy efficiency improvement (AEEI) in the CGE model is considered in this study according to Medium and Long-Term Energy Saving Special Planning [53]. Table 4 depicts the value of the parameter of AEEI in each sector.

\section{Data Source and Scenario Design}

\section{Data Source and Social Accounting Matrix}

The China Input-Output Table of China (CIOT) is to construct a social accounting matrix (SAM), which is the data source of the CGE model [54]. An energy-balanced table is constructed to analyze energy issues and the data of this table is from the China Statistical Yearbook [55]. Compared with Global Carbon Budget 2017 [56], it is declared that the $\mathrm{CO}_{2}$ emissions discussed is only from energy consumption, without biological breath, microbial decomposition, carbon sinks and carbon emissions from land and sea. Finally, Table 5 offers reclassification of the 139 sectors in the CIOT into 14 departments.

\section{Scenario Design}

According to varied documents in different periods, 5 scenarios with different combinations of changes in indirect tax and carbon tax on the coal industry have been proposed. Carbon tax rate is 60 yuan/tons of $\mathrm{CO}_{2}$, set according to relevant research and reports [57]. $\mathrm{BaU}$ (business as usual) is a scenario where there
Table 5. Description and coverage of sector classification and population classification.

\begin{tabular}{|c|c|}
\hline Sectors & Description \\
\hline AGR & Agriculture, forestry, animal husbandry and fishery \\
\hline COL & Coal mining and washing industry \\
\hline O_G & Petroleum and natural gas exploitation \\
\hline PAP & Paper industry \\
\hline CMT & Cement \\
\hline FER & Chemical fertilizer \\
\hline CMC & Chemicals \\
\hline STL & Steel smelting and rolling processing industry \\
\hline EQU & Equipment manufacturing industry \\
\hline ELC & Construction industry \\
\hline CST & Transportation \\
\hline TRA & Other industry \\
\hline OTH & Service \\
\hline SER & Rural population \\
\hline RUR & Urban population \\
\hline CTZ & \\
\hline & \\
\hline
\end{tabular}

are no changes in both tax rates. In the IT0 scenario, indirect tax of coal industry will reduce by $20 \%$, while it will rise by $20 \%$ in the IT 1 scenario. The CT scenario is a scenario in which the coal industry will be covered in a carbon tax system. In the ICT0 scenario, indirect tax of coal industry will be reduced by $20 \%$, while the coal industry will pay a carbon tax. In the ICT1 scenario, the indirect tax on the coal industry will rise by $20 \%$, while the coal industry will pay a carbon tax.

\section{Results and Discussion}

Economic Impact

\section{$G D P$}

Gross domestic product (GDP) in 2030 is illustrated in Fig. 3. In BaU, I0, I1, CT, ICT0 and ICT1 scenarios, GDP will be $86.857,86.868,86.833,86.835,86.800$,

Table 4. Autonomous energy efficiency improvement in the CGE model of each sector a

\begin{tabular}{|c|c|c|c|c|c|c|c|}
\hline Sectors & AGR & COL & O_G & PAP & CMT & FER & CMC \\
\hline AEEI & 0.025 & 0.006 & 0.006 & 0.015 & 0.015 & 0.02 & 0.015 \\
\hline Sectors & STL & EQU & ELC & CST & TRA & OTH & SER \\
\hline AEEI & 0.025 & 0.03 & 0.025 & 0.006 & 0.033 & 0.016 & 0.023 \\
\hline
\end{tabular}

aAEEI will be halved after 2020. 


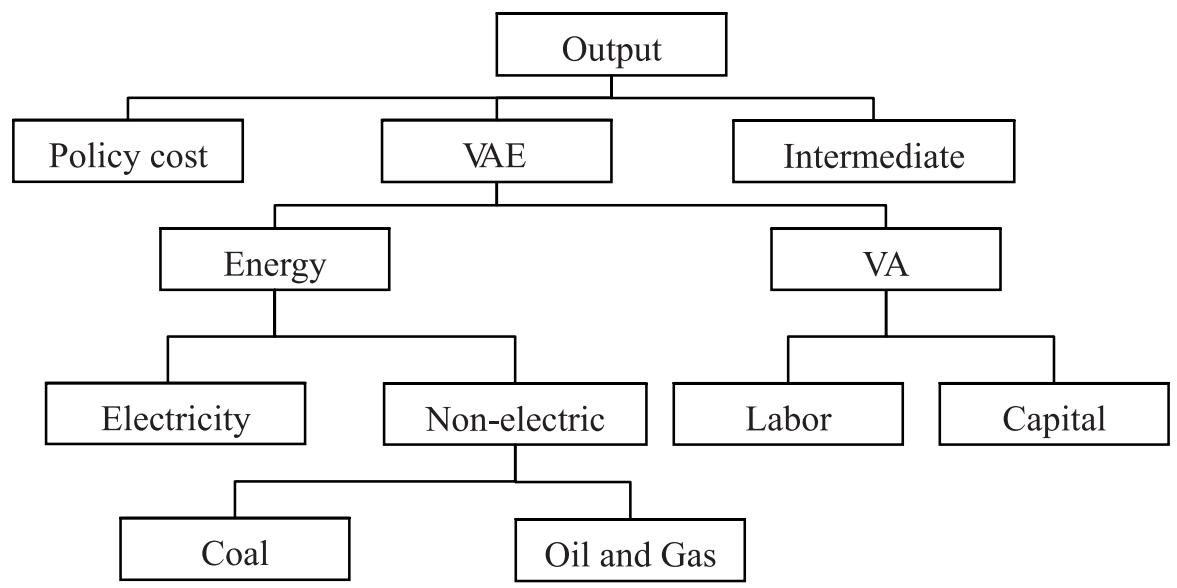

Fig. 2. Framework of production block in the CGE model.

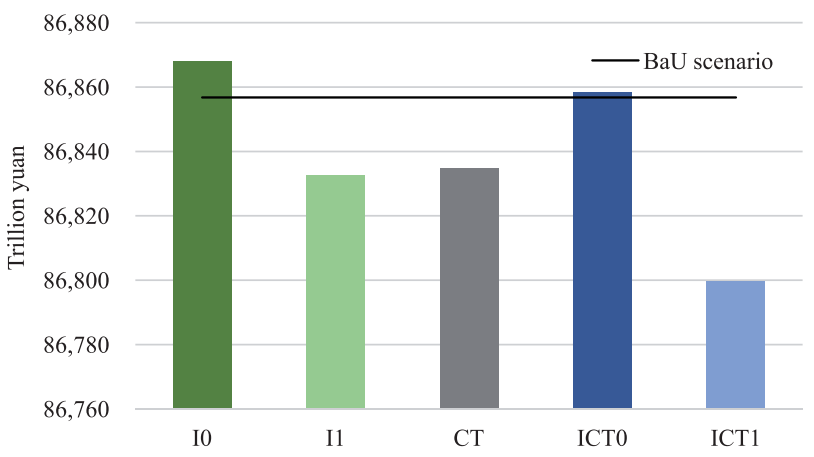

Fig. 3. GDP in all scenarios in 2030.

and 86.635 trillion yuan, respectively. The changes of GDP in CM scenarios will be $0.013 \%,-0.025 \%,-0.025$, $0.002 \%,-0.066 \%$ in I0, I1, CT, ICT0 and ICT1 scenarios, respectively, relative to that in the $\mathrm{BaU}$ scenario in 2030. It has been investigated that indirect tax and carbon tax in coal industry are negatively correlated with GDP. The more taxes the coal industry pays, the lower GDP will be. The main reason is that the coal sector provides the primary energy goods, which makes the coal sector belong to upstream enterprises in the energy supply chain of society. The energy goods are the basic factors of other industries, and the output and the price of coal will directly impact economic output. More details on the sectorial output and commodity output will be introduced in the next two sections. Moreover, the effect of carbon tax will be amplified by reducing the indirect tax: carbon tax will lead to GDP loss by 9.50 , 21.89 and 32.89 billion yuan when the indirect tax is changed by $-20 \%, 0 \%$ and $20 \%$. In another, the effect of indirect tax on GDP can be enhanced when carbon tax is implemented. GDP will increase or decrease by 11.20 or 24.21 billion yuan by reducing or increasing indirect tax, while the number will be 23.59 or 35.22 billion yuan when the carbon tax is implemented.

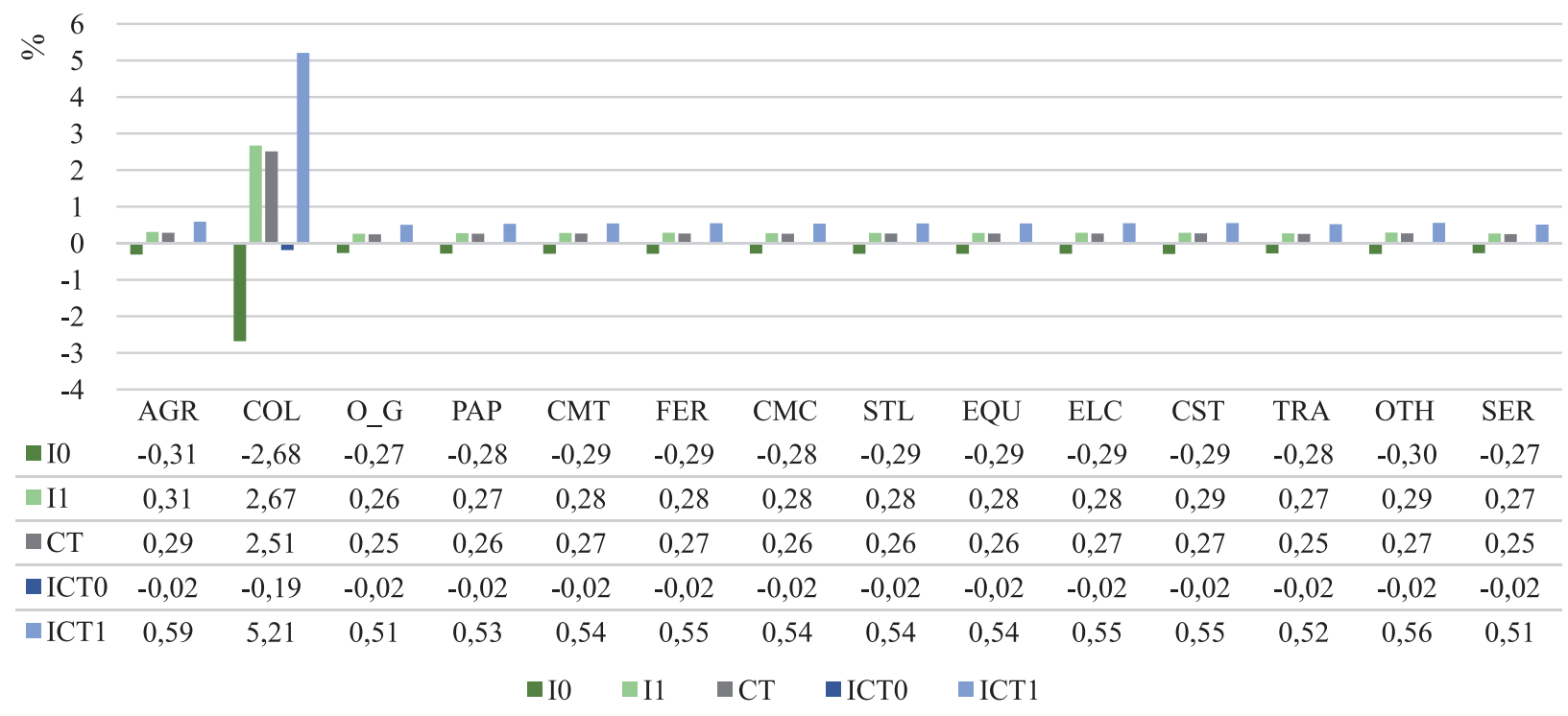

Fig. 4. Commodity price in all CM scenarios compared with the BaU scenario. 


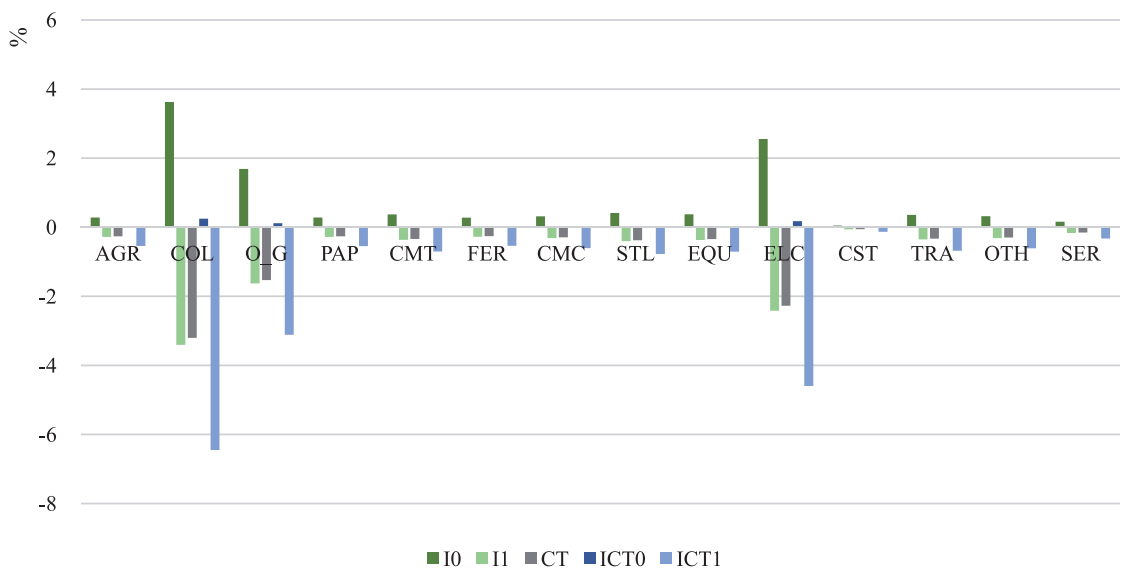

Fig. 5. Industrial output in all CM scenarios compared with BaU scenario.

\section{Commodity Price}

Fig. 4 shows the commodity prices in all sectors in 2030 relative to the prices in the $\mathrm{BaU}$ scenario. The commodity prices of coal industry in $\mathrm{I} 0, \mathrm{I} 1, \mathrm{CT}$, ICT0 and ICT1 scenarios will increase $-2.68 \%, 2.67 \%$, $2.51 \%,-0.19 \%$, and $5.2 \%$ compared with that in the $\mathrm{BaU}$ scenario, respectively. We found that the price of coal consumption will directly rise when the taxes of coal industries are high. Other industries will change their prices accordingly, but by no more than $1 \%$. The price will rise because of the increasing cost on carbon tax or indirect tax. it is suggested that an increase of $20 \%$ indirect taxes has basically the same impact on prices with the imposition of a carbon tax, because implementing a carbon tax or increasing indirect tax will directly raise the cost of the coal industry, and the increasing cost will increase the price of coal industries, and other energy-using industries will raise their price to cover the increasing parts of energy consumption.

\section{Industrial Output}

Fig. 5 depicts industrial output in all $\mathrm{CM}$ scenarios compared with the BaU scenario in 2030. The output of coal industry will increase by $3.63 \%,-3.41 \%,-3.20 \%$, $0.25 \%$, and $-6.45 \%$ in I0, I1, CT, ICT0 and ICT1 scenarios, respectively. While the output of oil and gas will rise by $1.69 \%,-1.63 \%,-1.53 \%, 0.12 \%$, and $3.11 \%$ in I0, I1, CT, ICT0 and ICT1 scenarios, respectively, and the output in electricity will be $2.55 \%,-2.42 \%,-2.27 \%$, $0.18 \%$ and $-4.60 \%$ in these scenarios, respectively. It is noticed that the energy output proves to be sensitive to the tax of coal industry, which means that only with a better tax system on the coal industry will energy consumption/output change significantly. This is because the coal market accounts for a huge proportion of the total energy market. It is also found that the elasticity of output in other energy production sectors with respect to the changes in coal taxation is not as sensitive as it is in the coal sector, such as the variation of the output of electricity. Although coal enterprises are the main upstream enterprises of the electricity industry, there are still some other power plants based on water, solar, wind and nuclear, etc., so that the output reduction in the electricity industry will be less than the coal industry.

\section{Resident Consumption}

Fig. 6 shows us the variation of household consumption in 2030. Except for coal consumption, all kinds of consumption will be hardly affected by the taxation on coal, and the changes will be under $0.33 \%$. However, coal consumption will be affected significantly by taxation, by from $-4.71 \%$ to $2.6 \%$. There are the three major findings of this section:

1. Coal consumption is more sensitive to the carbon tax and indirect tax compared with the consumption of other commodities, in both rural and urban populations. The reason is that coal tax will affect the cost of coal industries and coal market directly but will affect the cost of other industries indirectly.

2. Consumption by the urban population is more vulnerable to indirect tax and carbon tax on coal

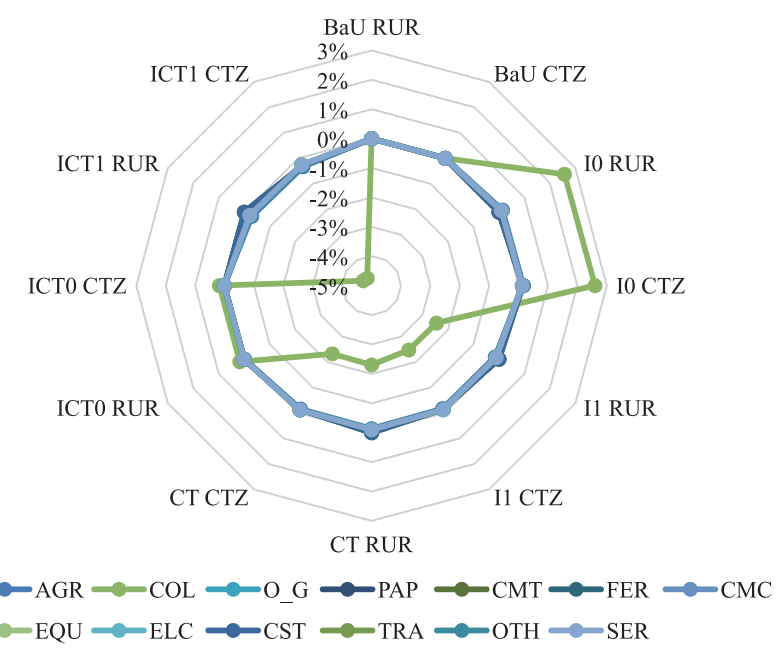

Fig. 6. Changes of consumption of residents in 2030. 


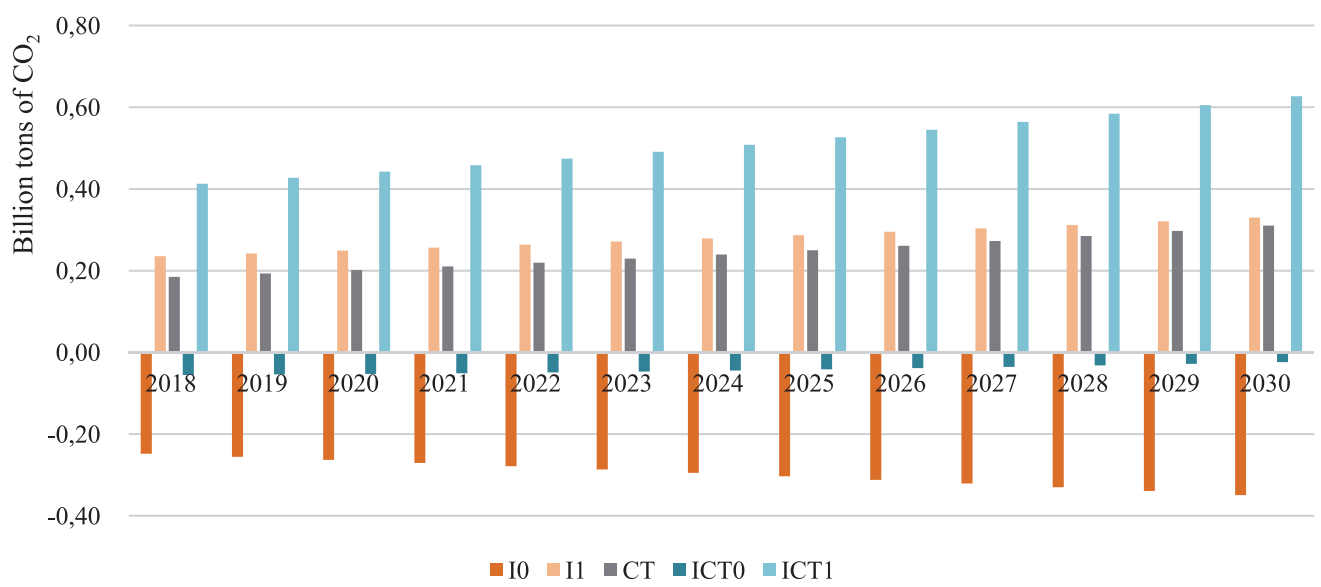

Fig. 7. $\mathrm{CO}_{2}$ reduction in all $\mathrm{CM}$ scenarios during 2018-2030.

industry than that of the rural population, which can be explained by citizens consuming more energy goods and more electronic products, which are made by energy-intensive industries.

3. The consumption of residents is less affected by coal tax compared with industrial output. It is because that consumption of coal and the proportion of it in enterprises are more than those in residents. So the tax variation will affect enterprises more than households.

\section{Energy and Environmental Impact}

$$
\mathrm{CO}_{2} \text { Reduction }
$$

$\mathrm{CO}_{2}$ reduction in all $\mathrm{CM}$ scenarios during 20182030 is illustrated in Fig. 7. It is simulated that indirect tax will change or carbon tax will be implemented in 2018, so the $\mathrm{CO}_{2}$ reduction effect will be calculated in 2018. $\mathrm{CO}_{2}$ emissions in I0 and ICT0 scenarios will rise by $0.25-0.35$ and $0.02-0.05$ billion tons of $\mathrm{CO}_{2}\left(\mathrm{Bt}-\mathrm{CO}_{2}\right)$ per year. The increase amount will be different in two scenarios: society will emit more $\mathrm{CO}_{2}$ in the $\mathrm{I} 0$ scenario, and less in the ICT0 scenario. The phenomenon indicates that the marginal emission reduction effect of carbon tax will increase more than the marginal emission increase effect of reducing indirect tax per year. $\mathrm{CO}_{2}$ emissions in I1, CT and ICT1 scenarios will be reduced by $0.24-0.33,0.19-0.31$ and $0.41-0.63$ Bt- $\mathrm{CO}_{2}$ per year. The reduction effect will increase over time. Moreover, we found that the impact of a taxation system on $\mathrm{CO}_{2}$ mitigation is very close to the impact on GDP, which can be confirmed by the results of carbon emission intensity (the next section will discuss the impact on $\mathrm{CO}_{2}$ emissions intensity).

\section{$\mathrm{CO}_{2}$ Emissions Intensity}

Fig. 8 depicts $\mathrm{CO}_{2}$ emission intensity in all scenarios during 2018-2030. The intensity will be highest in the I0 scenario, by $0.149-0.170$ tons of $\mathrm{CO}_{2} /$ thousand yuan, and it will be lowest in the ICT1 scenario by

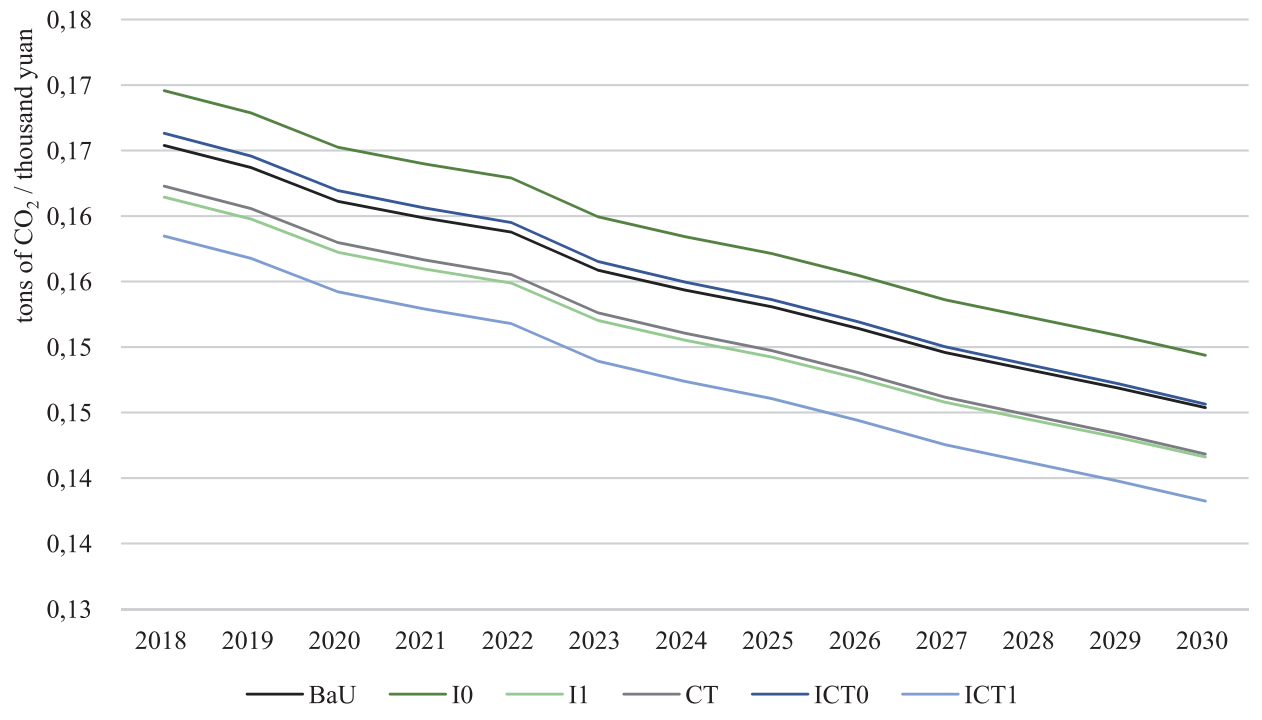

Fig. 8. $\mathrm{CO}_{2}$ emission intensity in all scenarios during 2018-2030. 
Table 6. Scenario design of indirect tax and carbon tax.

\begin{tabular}{|c|c|c|}
\hline & Indirect tax & Carbon tax \\
\hline BaU & 0 & 0 \\
\hline IT0 & $-20 \%$ & 0 \\
\hline IT1 & $+20 \%$ & 0 \\
\hline CT & 0 & $\sqrt{ }$ \\
\hline ICT0 & $-20 \%$ & $\sqrt{ }$ \\
\hline ICT1 & $+20 \%$ & $\sqrt{ }$ \\
\hline
\end{tabular}

0.138-0.158 tons of $\mathrm{CO}_{2} /$ thousand yuan. The $\mathrm{BaU}$ and ICT0 scenarios have similar carbon intensity performance, as do the CT and I1 scenarios. We found that although reducing indirect tax of coal industries can increase GDP performance, it will cause much more $\mathrm{CO}_{2}$ emissions, leading to carbon intensity being higher than in other scenarios. On the contrary, increasing the tax or implementing carbon tax can reduce $\mathrm{CO}_{2}$ emissions more than GDP, so that social $\mathrm{CO}_{2}$ emission intensity will increase. It turns out that the elasticity of $\mathrm{CO}_{2}$ emissions with respect to coal tax is more than that of GDP, which suggests that carbon tax and increasing indirect tax can reduce $\mathrm{CO}_{2}$ emissions intensity or increase $\mathrm{CO}_{2}$ emissions efficiency.

\section{Social Reduction Cost}

Social reduction cost is calculated here to measure the amount of GDP loss from unit $\mathrm{CO}_{2}$ emissions reduction, as shown in Table 7 . The following findings can be drawn according to the results:
1. Social reduction cost will decline over time. Only a levy tax on the coal industry will have long-term benefits in reducing emissions: the social reduction cost will decrease over time, which indicates that the society can adapt to new price changes in the long term and achieve optimal resource allocation.

2. The stronger the emission reduction ability the scenario is, the higher the social reduction cost would be. From high to low, the order of the average of reduction cost is ICT1, I1, CT ICT0 and I0 scenario, which is in the same order as the emission reduction capacity. The main reason may be that with the deepening of the emission reduction process, the cost of resource allocation is also increasing.

3. Also, we found that it is not reasonable to reduce indirect tax of the coal industry. As the social reduction cost is low, the increase rate of GDP cannot cover the increase of the $\mathrm{CO}_{2}$ emissions rate. This finding is similar to the results of $\mathrm{CO}_{2}$ emission intensity.

\section{Fossil Energy Consumption}

Fossil energy consumption of all industries is illustrated in Fig. 9. Fossil energy consumption in coal industry will be 430.07, 451.45, 410.22, 411.39, 431.53 and 392.67 million tons of coal equivalent (Mtce), which indicates that the coal industry is the most affected among all industries, ranging from $-8.70 \%$ to $4.97 \%$. The following vulnerable industries are oil and gas, and electricity: their variations range from $-5.67 \%$ to $3.14 \%$ and $-6.96 \%$ to $3.92 \%$ in $\mathrm{O}_{-} \mathrm{G}$ and ELC industry. It turns out that the carbon and indirect taxes on the coal industry can significantly impact fossil energy

Table 7. Social reduction cost during 2018-2030 (unit: yuan/tons of $\mathrm{CO}_{2}$ ).

\begin{tabular}{|c|c|c|c|c|c|}
\hline Year & I0 & I1 & $\mathrm{CT}$ & ICT0 & ICT1 \\
\hline 2018 & 146.59 & 173.47 & 170.62 & 157.18 & 183.65 \\
\hline 2019 & 139.96 & 167.82 & 164.99 & 151.17 & 178.50 \\
\hline 2020 & 133.48 & 162.50 & 159.68 & 145.46 & 173.76 \\
\hline 2021 & 126.21 & 156.20 & 153.40 & 139.05 & 167.97 \\
\hline 2022 & 118.22 & 149.17 & 146.39 & 132.05 & 161.45 \\
\hline 2023 & 110.95 & 143.26 & 140.46 & 126.15 & 156.23 \\
\hline 2024 & 101.95 & 135.40 & 132.60 & 118.65 & 148.97 \\
\hline 2025 & 92.13 & 126.70 & 123.90 & 110.61 & 140.87 \\
\hline 2026 & 81.83 & 117.67 & 114.85 & 102.57 & 132.50 \\
\hline 2027 & 70.83 & 108.03 & 105.20 & 94.41 & 123.57 \\
\hline 2028 & 58.77 & 97.26 & 94.42 & 85.91 & 113.50 \\
\hline 2029 & 45.86 & 85.70 & 82.86 & 77.73 & 102.66 \\
\hline 2030 & 32.08 & 73.37 & 70.52 & 70.60 & 91.10 \\
\hline Average & 96.84 & 130.50 & 127.68 & 116.27 & 144.21 \\
\hline
\end{tabular}




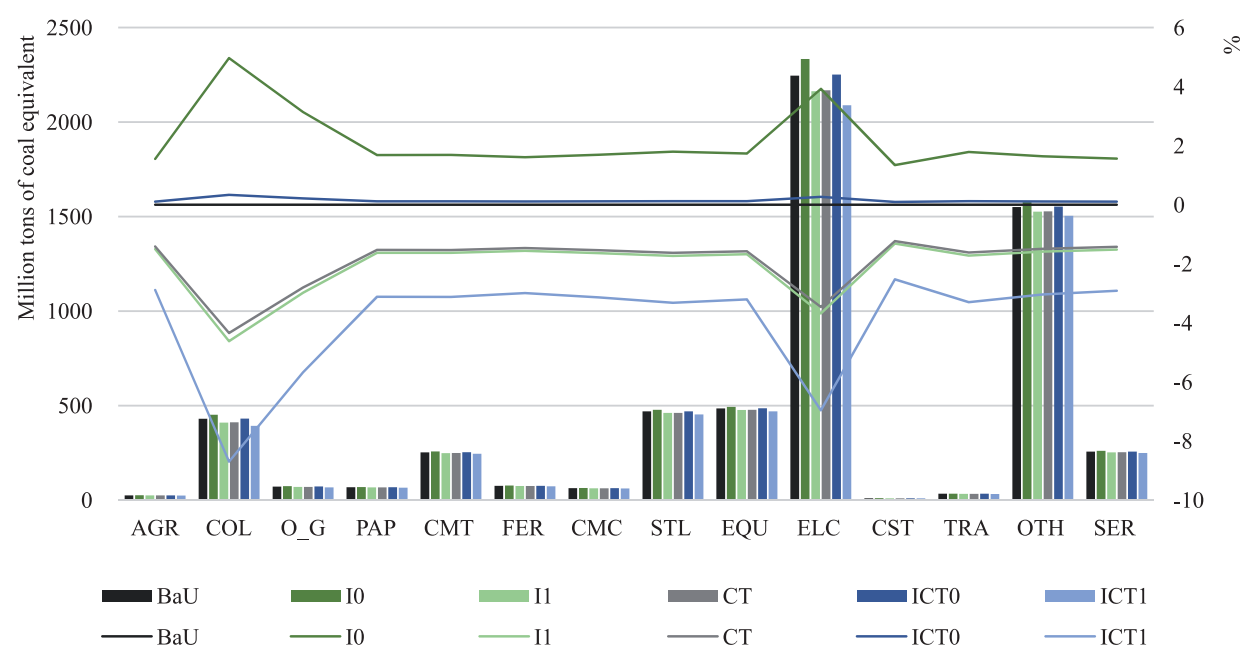

Fig. 9. Fossil energy consumption of all industries and and the variation of fossil energy consumption in CM scenarios compared with $\mathrm{BaU}$ scenario in 2030 .

consumption in energy production sectors - especially in the coal mining industry. Both of the tax systems (carbon tax and indirect tax on coal industry) can reduce fossil energy consumption in all industries and their influence on reducing fossil energy consumption in all industries is similar to each other. The main reason is that both of the taxes are applied to the coal industry, making the cost of coal consumption increase so that all the industries have to adjust energy use through a price mechanism. The reason why the electricity industry reduces the output is that the cost of electricity is increased by the rising price of coal consumption.

\section{Energy Efficiency}

Fig. 10 illustrates the changes in energy efficiency of all industries in CM scenarios compared with that in the $\mathrm{BaU}$ scenario in 2030. The energy efficiency of industry is measured by its output divided by energy consumption in this paper. Energy efficiency will decrease by $1.25-1.41 \%$ and $0.09 \%-0.10 \%$ in the $\mathrm{I} 0$ and ICT0 scenarios and will increase by $1.24-1.39 \%$, $1.17-1.31 \%$ and $2.41-2.71 \%$ in the I1, CT and ICT1 scenarios, respectively. it is indicated that both carbon tax and increasing indirect tax can improve all industries' energy efficiency, not only the efficiency of coal industry or energy industries, which reflects the powerful role of the coal industry in guiding the market. The cost of the coal industry can significantly impact the energy efficiency of all of society, and a tax can adjust the cost of the coal industry.

\section{Conclusions and Policy Implications}

\section{Conclusions}

The $\mathrm{CO}_{2}$ emissions from China's coal consumption account for $14.3 \%$ of the world's $\mathrm{CO}_{2}$ emissions. The taxation of China's coal industry affects the progress of world emissions reduction to some extent. We have now established six counter-measure scenarios of different

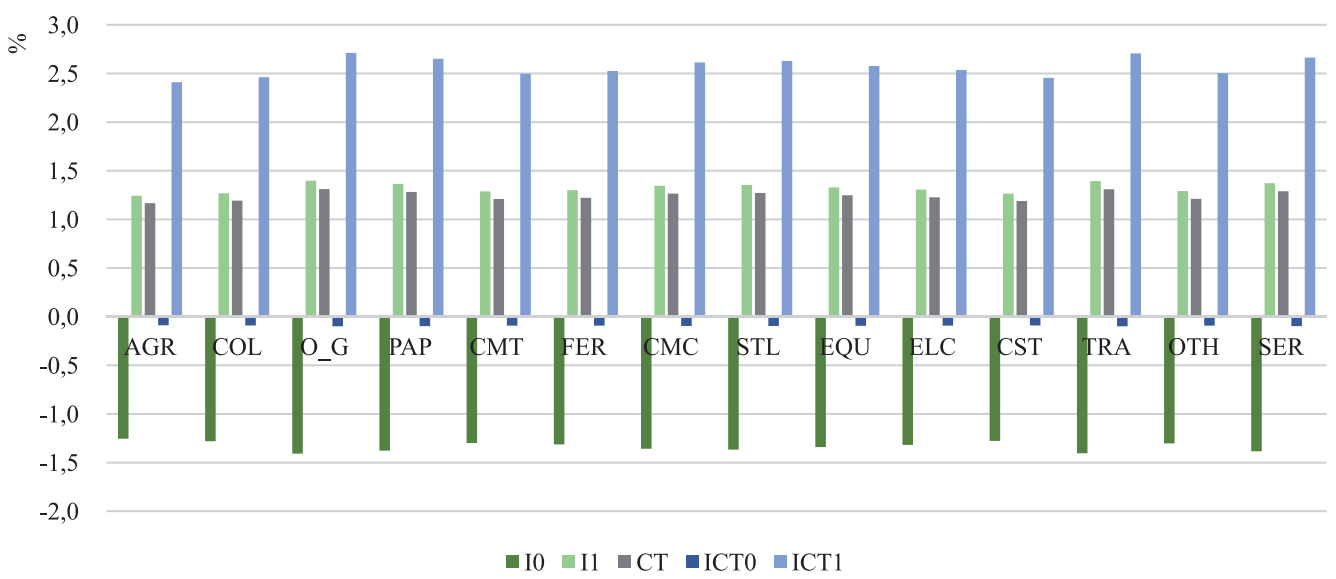

Fig. 10. Changes in energy efficiency of all industries in CM scenarios compared with that in BaU scenario in 2030. 
tax systems considering carbon tax and indirect tax, and constructing a dynamic recursive computable general equilibrium model to simulate the changes to the tax system of the coal industry. Finally, we have proposed the following conclusions.

For economic aspect, increasing or decreasing indirect tax can reduce or increase GDP performance in China accordingly. The effect of the carbon tax will be amplified by reducing the indirect tax; in addition, the effect of indirect tax on GDP can be enhanced when a carbon tax is implemented. Coal consumption is more sensitive to the carbon tax and indirect tax compared with the consumption of other commodities, in both rural and urban populations. The consumption of the urban population is more vulnerable to indirect tax and carbon tax on the coal industry than that of the rural population. The consumption of residents is less affected by coal tax compared with industrial output.

For energy and environmental aspects, it is suggested that the reduction effect will increase gradually, and the impact of a taxation system on $\mathrm{CO}_{2}$ mitigation is very similar to the impact on GDP. The elasticity of $\mathrm{CO}_{2}$ emissions is more than that of GDP, indicating that carbon tax and increasing indirect tax can reduce $\mathrm{CO}_{2}$ emissions intensity or increase $\mathrm{CO}_{2}$ emissions efficiency. Both carbon tax and indirect tax on coal industry can reduce fossil energy consumption in all industries, which reflects the powerful role of the coal industry in guiding the market. Social reduction cost will decline. The stronger the emissions reduction ability, the higher the social reduction cost.

\section{Policy Implications}

According to the conclusions we draw, the following policy suggestions provided are as follows:

1. As the elasticity of $\mathrm{CO}_{2}$ emissions with respect to taxing the coal industry is more than that of GDP, it is suggested that it is not reasonable to reduce indirect tax of the coal industry. On the contrary, increasing the tax of the coal industry can reduce $\mathrm{CO}_{2}$ emissions significantly and will suffer relatively less GDP loss. In this way China's government could increase the tax on the coal industry in order to reduce $\mathrm{CO}_{2}$ emissions and energy consumption.

2. As the economic, energy and environmental performance of carbon tax and increasing indirect tax are similar to each other, it is suggested that China can increase indirect tax on the coal industry as one of the methods to build a low-carbon economy, because increasing tax on the coal industry not only aims at $\mathrm{CO}_{2}$ reduction in the coal industry, but aims at the reduction of the whole country as well. Moreover, for the other countries that are not coal dominated, increasing indirect tax on oil industries where oil is dominant and on gas industries where natural gas is dominant.

3. Increasing indirect taxes while levying carbon taxes on coal industry will double the effect of reducing
$\mathrm{CO}_{2}$ emissions and energy consumption, as well as the GDP, although social reduction cost may be higher, too. Thus, it is suggested that if $\mathrm{CO}_{2}$ reduction is strongly demanded, a mixed taxation system can be applied.

4. It turns out that social reduction cost will be reduced over time, which indicates that increasing tax on the coal industry will propose long-term benefits in reducing $\mathrm{CO}_{2}$ emissions. So, this paper strongly recommends that such policies should be applied in order to reach long-term interests as soon as possible.

\section{Acknowledgements}

This paper was supported by the Social Science Foundation of Beijing (project ID.15JGB050).

\section{Conflicts of Interest}

We declare no conflict of interest.

\section{References}

1. LI W., JIA Z., ZHANG H. The impact of electric vehicles and CCS in the context of emission trading scheme in China: A CGE-based analysis. Energy, 119, 800, 2017.

2. WEI P., CUI H., GANG M. Scenario Analysis of Energy Conservation and $\mathrm{CO}_{2}$ Emissions Reduction Policies in China's Iron and Steel Sector. Polish Journal of Environmental Studies, 26 (5), 2307, 2017.

3. MORAN D.D., WACKERNAGEL M., KITZES J.A., GOLDFINGER S. H., BOUTAUD A. Measuring sustainable development - Nation by nation. Ecological Economics, 64 (3), 470, 2008.

4. vAN WEENEN J.C. Towards sustainable product development. Journal of Cleaner Production, 3 (1), 95, 1995.

5. GAO-LIN W., MEI-RU W., TING G., TIAN-MING H., DAVIDSON G. Effects of mowing utilization on forage yield and quality in five oat varieties in alpine area of the eastern Qinghai-Tibetan Plateau. African Journal of Biotechnology, 9 (4), 461, 2010.

6. LIU Y., WU G.L., DING L.M., TIAN F.P., SHI Z.H. Diversity-Productivity Trade-off During Converting Cropland to Perennial Grassland in the Semi-arid Areas of China. Land Degradation and Development, 28 (2), 699, 2017.

7. LECHOWSKA E. The impact of embankment construction on floodplain land use in the context of its influence on the environment: A case study of selected cities in Poland. Polish Journal of Environmental Studies, 26 (2), 655, 2017.

8. LI W., JIA Z. Carbon tax, emission trading, or the mixed policy: which is the most effective strategy for climate change mitigation in China? Mitigation and Adaptation Strategies for Global Change, 22 (6), 973, 2017.

9. CALLAN T., LYONS S., SCOTT S., TOL R.S.J., VERDE S. The distributional implications of a carbon tax in Ireland. Energy Policy, 37 (2), 407, 2009. 
10. LIN B., JIA Z. The energy, environmental and economic impacts of carbon tax rate and taxation industry: A CGE based study in China. Energy, 159, 2018.

11. RITTER R., LANDSCHÜTZER P., GRUBER N., FAY A.R., IIDA Y., JONES S., ... ZENG J. Observation-Based Trends of the Southern Ocean Carbon Sink. Geophysical Research Letters, 44 (24), 12, 339, 2017.

12. BASTVIKEN D., TRANVIK L.J., DOWNING J., CRILL J.A., M P., ENRICH-PRAST A. the Continental Carbon Sink. Science, 331 (Table 1), 50, 2011.

13. XIONG C., YANG D., HUO J., WANG G. Agricultural net carbon effect and agricultural carbon sink compensation mechanism in Hotan prefecture, China. Polish Journal of Environmental Studies, 26 (1), 365, 2017.

14. LI W., JIA Z. The impact of emission trading scheme and the ratio of free quota: A dynamic recursive CGE model in China. Applied Energy, 174, 1, 2016.

15. BABATUNDE K.A., BEGUM R.A., SAID F.F. Application of computable general equilibrium (CGE) to climate change mitigation policy: A systematic review. Renewable and Sustainable Energy Reviews. 2017.

16. OH H., HYON J., KIM J.O. Korea's approach to overcoming difficulties in adopting the emission trading scheme. Climate Policy, 17 (8), 947, 2017.

17. ZHANG H., CAO L., ZHANG B. Emissions trading and technology adoption: An adaptive agent-based analysis of thermal power plants in China. Resources, Conservation and Recycling, 121, 23, 2017.

18. ZHANG J., ZHANG Y. Carbon tax, tourism $\mathrm{CO}_{2}$ emissions and economic welfare. Annals of Tourism Research, 69, $18,2018$.

19. LIN B., LI X. The effect of carbon tax on per capita $\mathrm{CO}_{2}$ emissions. Energy Policy, 39 (9), 5137, 2011.

20. MARDONES C., BAEZA N. Economic and environmental effects of a $\mathrm{CO}_{2}$ tax in Latin American countries. Energy Policy, 114, 262. 2018.

21. BONNET C., BOUAMRA-MECHEMACHE Z., CORRE T. An Environmental Tax Towards More Sustainable Food: Empirical Evidence of the Consumption of Animal Products in France. Ecological Economics, 147 (April 2016), 48, 2018.

22. MARDONES C., FLORES B. Effectiveness of a $\mathrm{CO}_{2}$ tax on industrial emissions. Energy Economics, 71, 370, 2018.

23. FARAJZADEH Z. Emissions tax in Iran : Incorporating pollution disutility in a welfare analysis. Journal of Cleaner Production, 186, 618, 2018.

24. LI Z., DAI H., SUN L., XIE Y., LIU,Z., WANG P., YABAR $\mathrm{H}$. Exploring the impacts of regional unbalanced carbon tax on $\mathrm{CO}_{2}$ emissions and industrial competitiveness in Liaoning province of China. Energy Policy, 113, 9, 2018.

25. WANG B., LIU L., HUANG G.H., LI W., XIE Y.L. Effects of carbon and environmental tax on power mix planning A case study of Hebei Province, China. Energy, 143, 645, 2018.

26. BENAVIDES C., GONZALES L., DIAZ M., FUENTES R., GARCÍA G., PALMA-BEHNKE R., RAVIZZA C. The impact of a carbon tax on the chilean electricity generation sector. Energies, 8 (4), 2674, 2015.

27. FREIRE-GONZÁLEZ J., HO M.S. Environmental fiscal reform and the double dividend: Evidence from a dynamic general equilibrium model. Sustainability (Switzerland), 10 (2), 2018.

28. National Development and Reform Commission. Enhanced actions on climate change: China's intended nationally determined contributions. Retrieved from http://www. ndrc.gov.cn/gzdt/201506/t20150630_710226.html 2015.
29. National Development and Reform Commission. National carbon emission trading market construction plan (power generation industry). Retrieved from http://qhs.ndrc.gov. cn/qjfzjz/201712/t20171220 871258.html 2017.

30. China Economic Herald. Is the carbon tax really coming? Comprehensive analysis of the ups and downs of the introduction of the carbon tax. Retrieved from http://www. tanpaifang.com/tanshui/2016/1028/57396.html 2016.

31. TANG L., SHI J., YU L., BAO Q. Economic and environmental influences of coal resource tax in China: A dynamic computable general equilibrium approach. Resources, Conservation and Recycling, 117, 34, 2017.

32. LIU H., CHEN Z.M., WANG J., FAN J. The impact of resource tax reform on China's coal industry. Energy Economics, 61, 52, 2017.

33. SONG W., BI G. BING, WU J., YANG F. What are the effects of different tax policies on China's coal-fired power generation industry? An empirical research from a network slacks-based measure perspective. Journal of Cleaner Production, 142, 2816, 2017.

34. CHEN Z.M., LIU Y., QIN P., ZHANG B., LESTER L., CHEN G., ... ZHENG X. Environmental externality of coal use in China: Welfare effect and tax regulation. Applied Energy, 156, 16, 2015.

35. JEONG S.J., KIM K.S., PARK J.W., LIM D. SOON, LEE S. MOON. Economic comparison between coal-fired and liquefied natural gas combined cycle power plants considering carbon tax: Korean case. Energy, 33 (8), 1320, 2008.

36. CHEN W., ZHOU J.F., LI S.Y., LI Y.C. Effects of an energy tax (carbon tax) on energy saving and emission reduction in guangdong province-based on a CGE model. Sustainability (Switzerland), 9 (5), 2017.

37. BP. Statistical Review of World Energy 2017. Retrieved from https:/www.bp.com/content/dam/bp/en/corporate/ pdf/energy-economics/statistical-review-2017/bpstatistical-review-of-world-energy-2017-full-report.pdf 2017.

38. BORGOMEO E., VADHEIM B., WOLDEYES F.B., ALAMIREW T., TAMRU S., CHARLES K.J., WALKER O. The Distributional and Multi-Sectoral Impacts of Rainfall Shocks: Evidence From Computable General Equilibrium Modelling for the Awash Basin, Ethiopia. Ecological Economics, 146, 621, 2018.

39. SIAGIAN U.W.R., YUWONO B.B., FUJIMORI S., MASUI T. Low-carbon energy development in Indonesia in alignment with Intended Nationally Determined Contribution (INDC) by 2030. Energies, 10 (1), 2017.

40. CHEN Z., HUANG Z., NIE P. Industrial characteristics and consumption efficiency from a nexus perspective Based on Anhui's Empirical Statistics. Energy Policy, 115, 281, 2018.

41. CUI L.B., PENG P., ZHU L. Embodied energy, export policy adjustment and China's sustainable development: A multi-regional input-output analysis. Energy, 82, 457, 2015.

42. HE Y., LIN B. The impact of natural gas price control in China: A computable general equilibrium approach. Energy Policy, 107, 524, 2017.

43. HOSO N. Impact of border barriers, returning migrants, and trade diversion in Brexit: Firm exit and loss of variety. Economic Modelling, 69, 193, 2018.

44. WU T., ZHANG M., O, X. Analysis of future vehicle energy demand in China based on a Gompertz function method and computable general equilibrium model. Energies, 7 (11), 7454, 2014 
45. LIN B., JIA Z. The impact of Emission Trading Scheme (ETS) and the choice of coverage industry in ETS: A case study in China. Applied Energy, 205, 1512, 2017.

46. LIN B., JIA Z. Impact of quota decline scheme of emission trading in China: A dynamic recursive CGE model. Energy, 149, 190, 2018.

47. HOSOE N., GASAWA K., HASHIMOTO H. Textbook of Computable General Equilibrium Modelling: Programming and Simulations. New York: St Martin's Press, Palgrave Macmillan, 2010, pp. xix, 235, 2, 2010.

48. HOSOE N. Computable general equilibrium modeling with GAMS. Tokyo: National Graduate Institute for Policy Studies, 1. Retrieved from http://citeseerx.ist.psu.edu/ viewdoc/download?doi=10.1.1.121.81\&rep=rep1\&type $=$ pdf 2004.

49. LIN B.Q., LI A.J. Impacts of removing fossil fuel subsidies on China: How large and how to mitigate? Energy, 44 (1), 741, 2012.

50. HE Y., LIU Y., XIA T., DU M., GUO H. The optimal price ratio of typical energy sources in Beijing based on the computable general equilibrium model. Energies, 7 (5), 2961, 2014.

51. WU J., FAN Y., XIA Y. How Can China Achieve Its Nationally Determined Contribution Targets Combining
Emissions Trading Scheme and Renewable Energy Policies? Energies, 10 (8), 1166, 2017.

52. The Central People's Government of the People's Republic of China. National Population Development Plan (2016-2030). Retrieved February 3, 2018, from http://www.nhfpc.gov.cn/bgt/gwywj2/201701/ a6dd45cf1660432c91a9ada5e758a4a2.shtml 2017.

53. National Development and Reform Commission. Medium and Long-term Energy Saving Special Planning. Retrieved from http://xwzx.ndrc.gov.cn/xwfb/200506/ t20050628_104993.html 2005.

54. China Input-Output Association. 2010 Input-Output Table. Retrieved February 3, 2018, from http://www.iochina.org. cn/Download/xgxz.html 2015.

55. National Bureau of Statistics. China Statistical Yearbook (2014). Retrieved February 3, 2018, from http://www.stats. gov.cn/tjsj/ndsj/ 2015.

56. LE QUÉRÉ C., ANDREW R.M., FRIEDLINGSTEIN P., SITCH S., PONGRATZ J., MANNING A.C., ... ZHU D. Global Carbon Budget 2017. Earth System Science Data Discussions, 1, 2017.

57. China Economic Herald. Is the carbon tax really coming? Retrieved from http://www.chinadevelopment.com.cn/ news/ny/2016/10/1092535.shtml 2016. 